\title{
Stabilization of clayey soil using Gypsum
}

\author{
Bussa Reethu \\ Mankala Sumanth Kumar \\ Gunde Sharath \\ Batchu Ramanjaneyulu \\ Dr. Ram Kishore Manchiryal
}

\author{
MIDDLE EAST COLLEGE \\ Middle East College \\ Middle East College \\ Middle East College \\ Middle East College
}

The poor soil properties result in foundation failures of the structure which further causes in cracks of structural elements and walls. To avoid this, it is essential to enhance the soil properties. Soil stabilization is one of the processes to improve the engineering properties of the soil and thus making it more stable. It is required when the soil available for construction is not appropriate for the intended purpose.

In this research, for stabilizing clayey soil and to achieve higher strength in minimum time period, gypsum $\left(\mathrm{CaSO}_{4} \cdot 2 \mathrm{H}_{2} \mathrm{O}\right)$ is used as one of the soil stabilizing agents. Experiments were planned to evaluate the properties of clayey soil on the addition of different percentages of Gypsum i.e., 2\%, 4\%, 6\% and $8 \%$ to the existing soil. Tests conducted on clayey soil mixed with Gypsum included are, Atterberg's Limits, Specific Gravity and Standard Proctor Test. A comparison between the properties of clayey soil, clayey soil mixed with Gypsum is done to understand the effect of Gypsum addition on soil properties. It was observed that the soil properties were enhanced for $6 \%$ of Gypsum addition to the soil.

\section{Introduction}

Soil is the mixture of rocks, crystals, biological matter and water. It is generally made of pieces of rock battered by air, water flow, heat, etc., and varying amounts of dirt. The soil type is based on the quantity of dirt it holds and on the size of the rock pieces. The grains may be minor and even, like clay, or they can be bigger, like sand or a piece of stone. Soil plays a crucial role in the ecosystem as it is the place where animals, human beings, small organism live and plants grow, soil is the barrier for velocity of water, soil recycles minerals from inorganic materials.

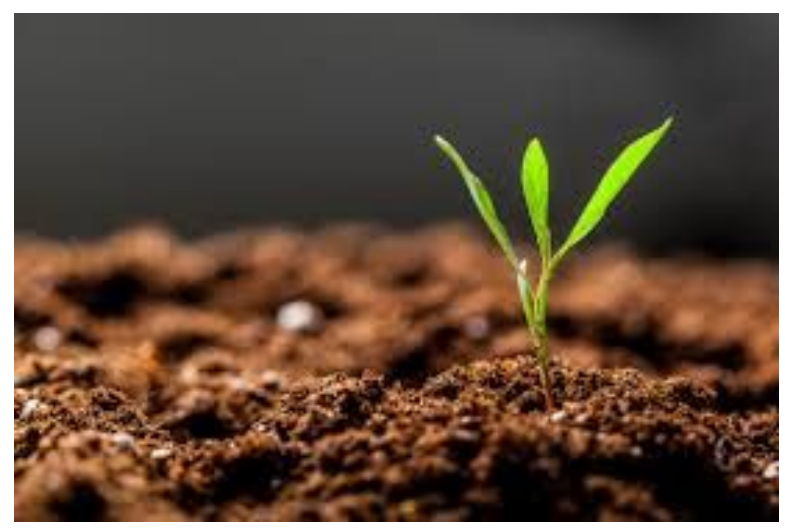

Figure 1. Plant origin

From the engineering point of view, soils are either occurred naturally or it is artificially made (Barnes, 2010). On this basis, soil is classified, and many types of soil can be found now. Amongst all of them, Black cotton soil is taken now for research purpose, as it is found to be the most troublesome soil for engineers. This soil occupies about $3 \%$ of the world land area. These soils are 
generally clayey, deep, impermeable and are formed by lava basaltic rocks, so it is dark in color. Chemically black soil consists of $\mathrm{CaCO}_{3}, \mathrm{Fe}, \mathrm{Mg}, \mathrm{Al}$ and $\mathrm{K}$ but they are deficient in $\mathrm{N}, \mathrm{P}$ and some organic matter. Black cotton soils exhibit high swelling and shrinkage rate, when exposed to environmental changes, due to the presence of large amounts of Montmorillonite in it.

Consequently, expansion and occurrence of cracks in the soil mass occurs without prior notice, which is very dangerous in construction and structure on it. The self-tilling nature of soil is the reason for their ability to hold water for long time and fertility. This capacity is used for cultivating cotton; hence this soil is called as Black cotton soil.

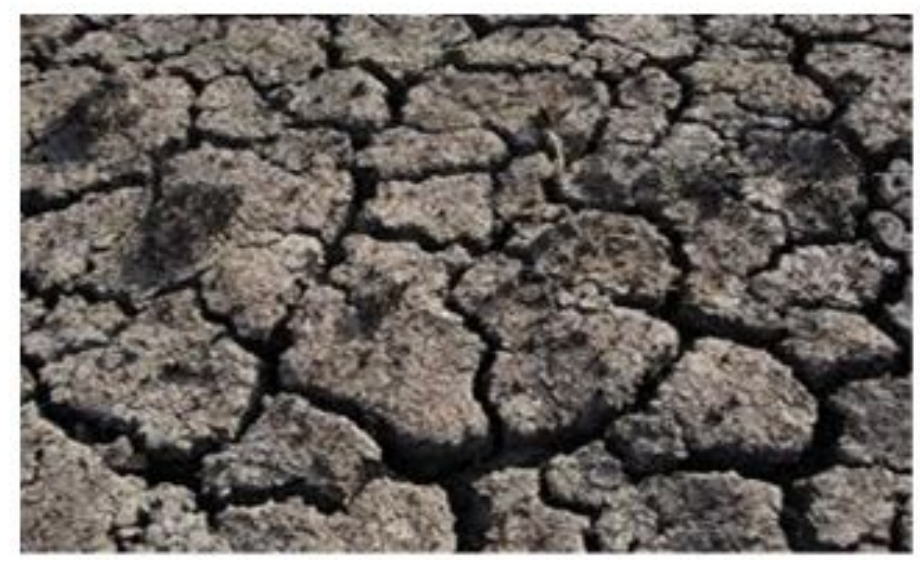

Figure 2. Black Cotton Soil in field

Structures requires a stable and steady foundation for constructing and to have long term strength. Ultimately, the foundation of any structure should transfer its load to the soil. If a structure is built on weak soil, in course of time, the soil compacts and consolidates resulting in the settlement of the structure (Brahmachary, 2017). The engineering properties of the soil also differ from place to place and depends mainly on soil mineral deposits, water table, soil water relationship etc., because of which soil properties are problematic and unsuitable for construction. To rectify this problem, weak soil should be stabilized (Tiwari et al., 2014).

Soil Stabilization is the technique to satisfy the engineering needs of Geotechnical Engineers (AttohOkine, 1995). Improvements and changes in the soil can be made either by modification or by stabilizing the soil or by using both (Kassim et al., 2005). Soil modification is done by applying physical pressure(like compacting, blasting, grouting, etc.) on the soil to change the index properties whereas Soil stabilization is the method in which the soil is treated with a stabilizing agent such that the soil gets strengthened and tough to advance the soil properties, so that the soil is absolutely fit for construction. Soil Stabilization may be defined as the technique adopted to improve the engineering properties of weaker soil by using different stabilizing agents. After stabilization, the soil becomes more stable by reducing permeability, compressibility and there will be rise in shear strength value, thus improving the bearing capacity of soil (Dhon \& Borkar, 2018). Enhancing the soil properties by using waste or inexpensive materials is broadly proposed from the ecofriendly point of view. Here, in this study, Gypsum is used as a stabilizing agent.

The soil sample was collected from the Geotechnical lab, CVR college of Engineering, Ibrahimpatnam, Hyderabad, India. Wet sieve analysis is carried out on the collected soil. Soil sample of $500 \mathrm{gm}$ which passed through a $4.25 \mathrm{~mm}$ sieve is taken and washed using water to remove all the lumps. Then the residual sample is kept for oven drying. After 24 hours, residual weight is observed to be $460 \mathrm{gm}$. It is found that about $90 \%$ of the soil sample is passed through a 75-micron sieve. 


\section{Journal of Student Research}

Fourth Middle East College Student Research Conference, Muscat, Sultanate of Oman

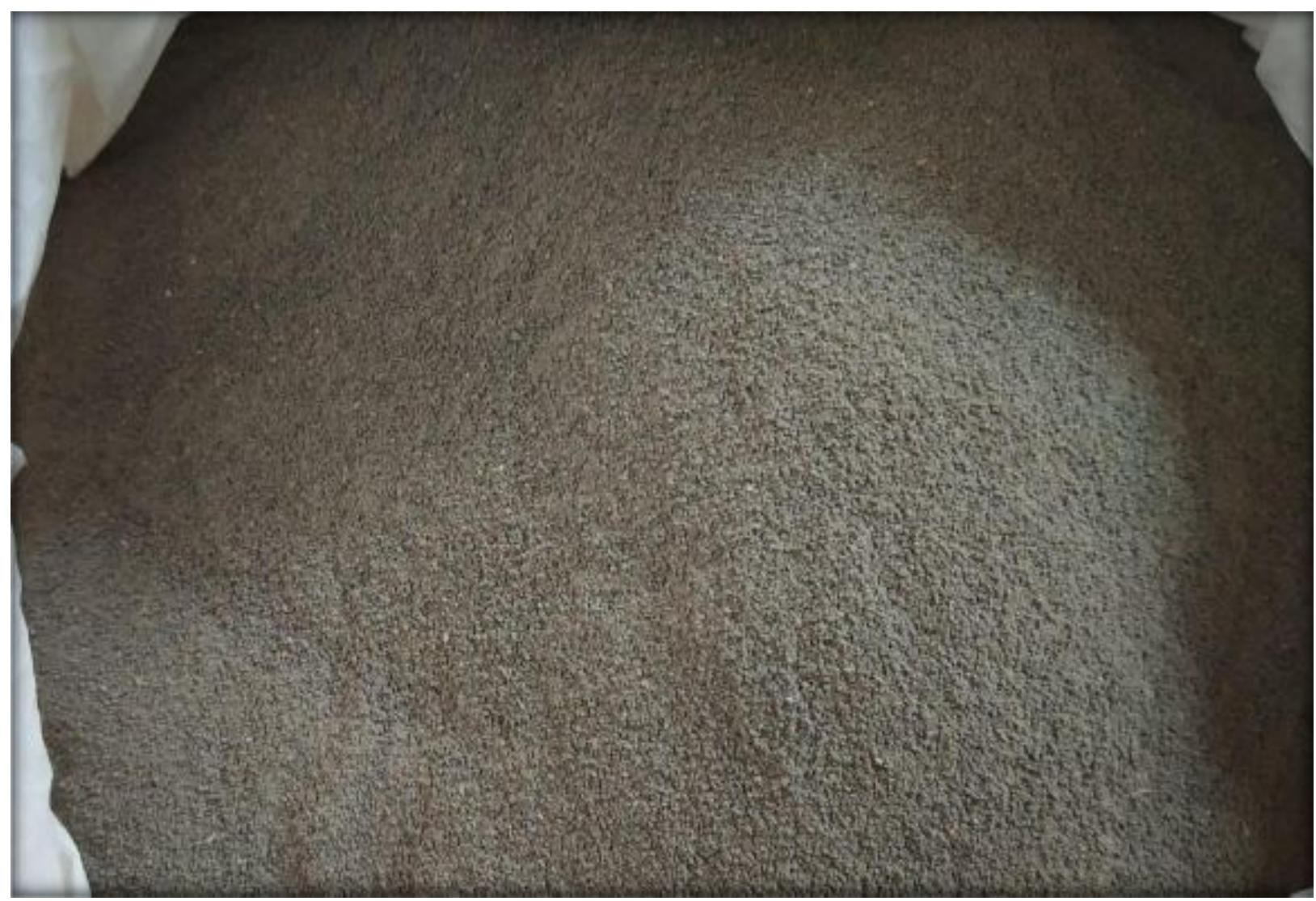

Figure 3. Black Cotton Soil

Gypsum is made up of $79 \%$ of $\mathrm{CaSO}_{4}$ and $21 \%$ of $\mathrm{H}_{2} \mathrm{O}$. So, it is also called as Hydrous Calcium Sulphate. The chemical formula of gypsum is $\mathrm{CaSO}_{4} \cdot 2 \mathrm{H}_{2} \mathrm{O}$. Gypsum is a by-product of many industrial processes. Gypsum increases the strength of the soil to regulate the swelling caused by environmental changes.

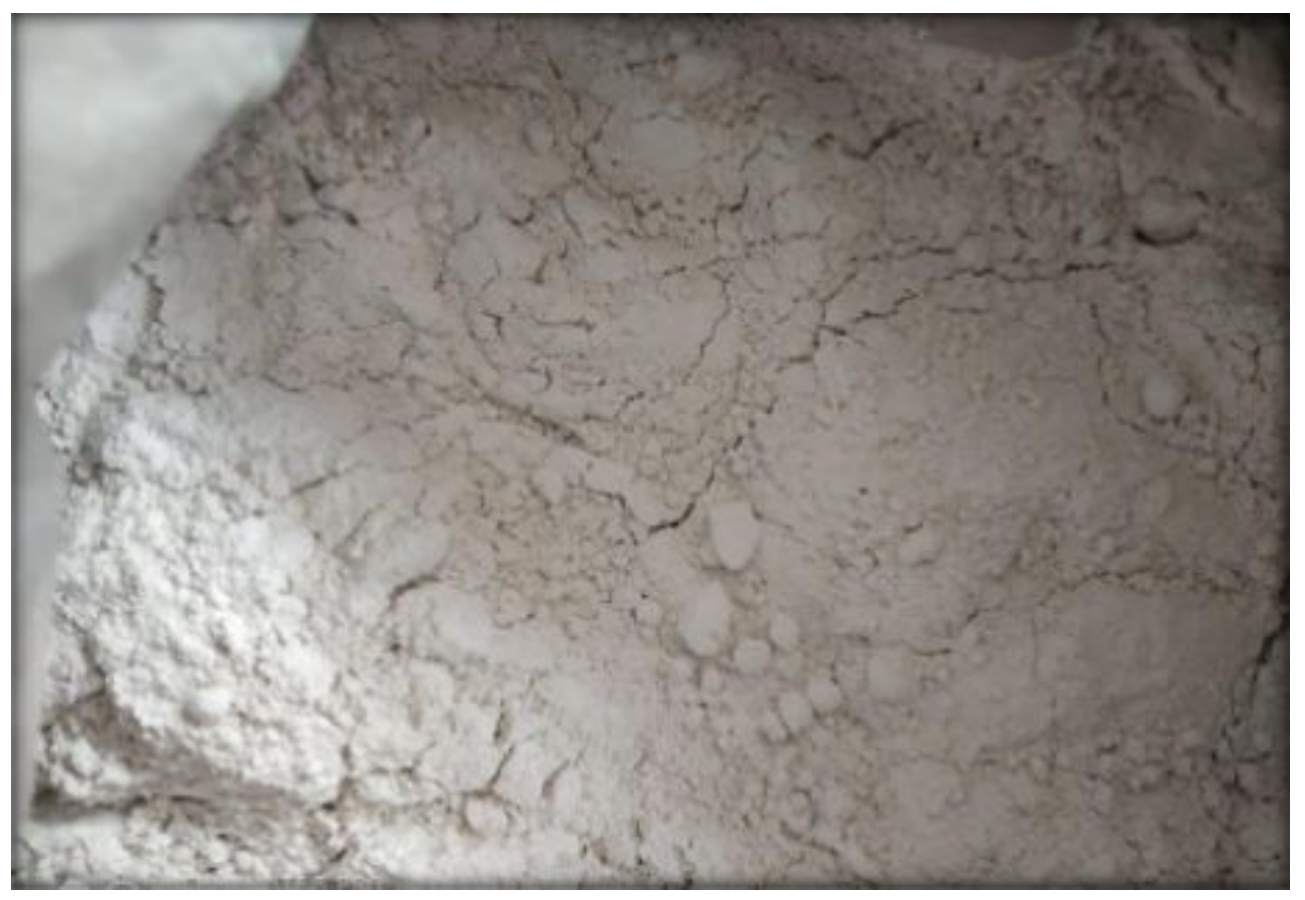

Figure 4. Gypsum 


\section{Experimental Details}

\subsection{Methodology}

The methodology adopted in the process of stabilization of soil is as follows:

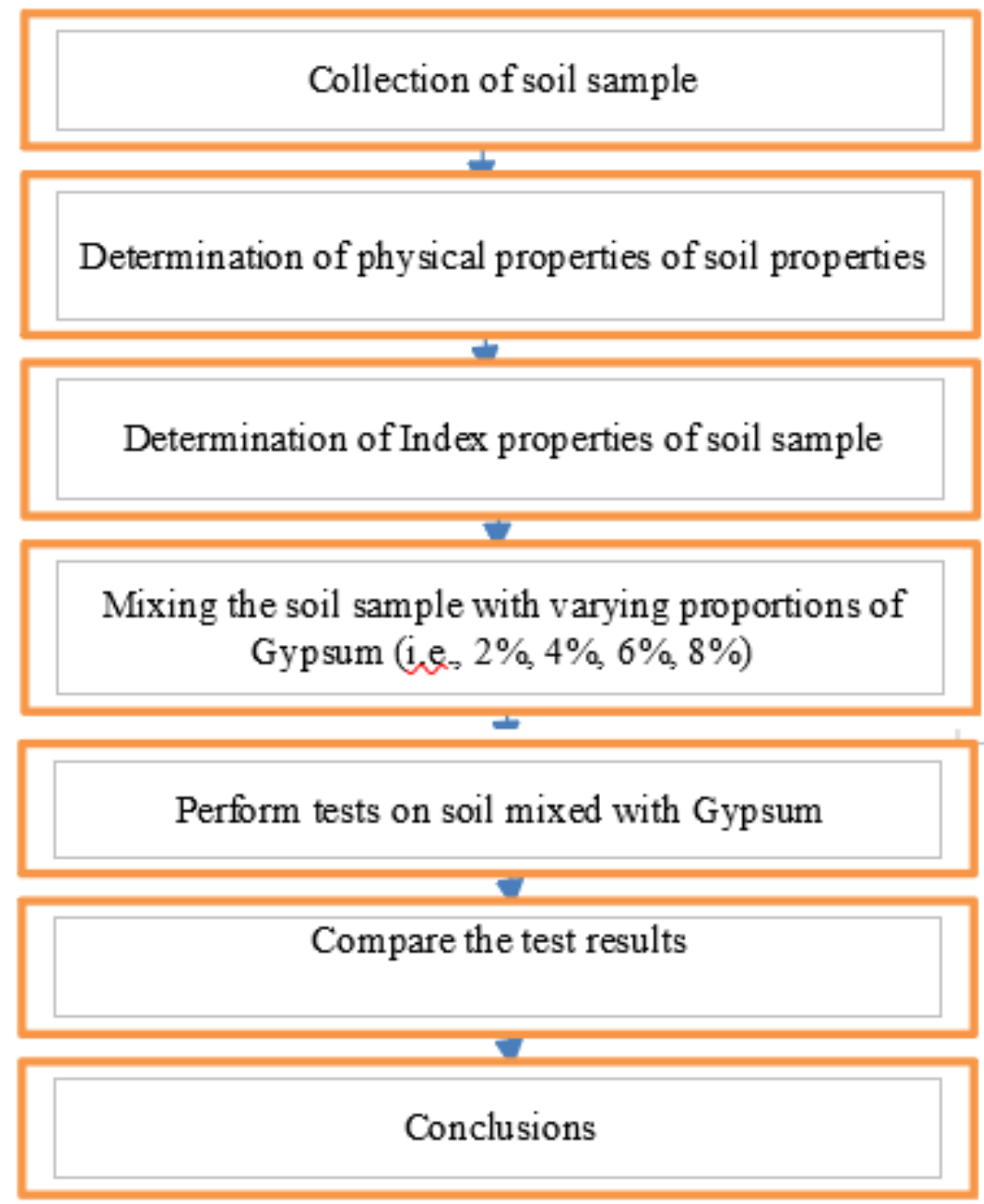

Figure 5. Flow diagram showing Methodology Adopted

\subsection{Preparation of Sample}

Collected samples were brought to the laboratory and are kept in oven for 24 hours and then spread on the floor to make the samples dry. Then after, the soil was broken into small pieces by using wooden hammer.

The soil was passed through $40 \mathrm{~mm}$ standard sieve to make the soil free from foreign materials. Water content of the sample is determined. Then the soil is mixed with the required proportions of Gypsum (i.e., 2\%, 4\%, 6\% and $8 \%$ ) by replacing the soil. Then the tests are performed on the samples prepared.

\subsection{Experiment Particulars}

Tests performed on the soil sample are: 
1. Specific Gravity Test

2. Atterberg's Limits:
a) Liquid Limit
b) Plastic Limit

3. Standard Compaction Test

\section{Test Procedures}

\subsection{Specific Gravity (ASTM D-854)}

- Dry the volumetric flask and clean thoroughly

- Weigh the Specific Gravity bottle and note the value as $\mathrm{W}_{1}$

- Then after, fill the bottle with $20 \%$ sample and then weigh the bottle with sample and note the weight as $\mathrm{W}_{2}$.

- The flask filled with $20 \%$ soil was then filled with water till the mark and weighed as $\mathrm{W}_{3}$.

- At last, the flask was filled with water completely up to the mark i.e. bottom of meniscus and the weight is measured and noted as $\mathrm{W}_{4}$.

- Using the formula available, determine the specific gravity of each sample

- Generally, the specific gravity value of clay and silty clay was observed to be 2.67-2.9 (Das, 2009). 


\section{Journal of Student Research}

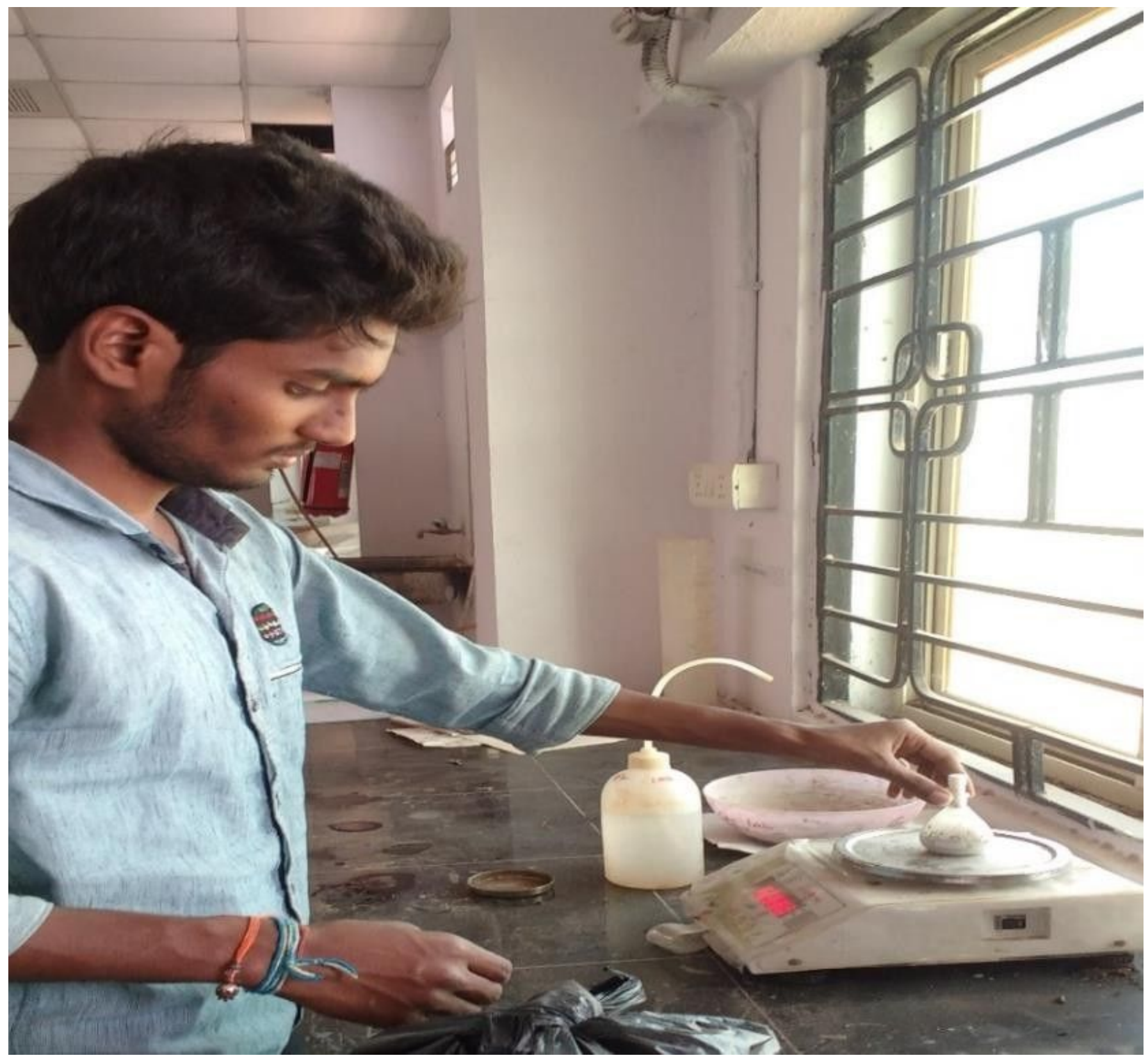

Figure 6. Performing Specific Gravity Test

\subsection{Liquid Limit Test (ASTM D-4318)}

- 250 grams of soil sample is passed through a $40 \mathrm{~mm}$ sieve and that sample is mixed with some amount of water to make it a uniform mix.

- Place some of that sample in the brass cup of Casagrande's apparatus, with the help of a spatula and then smoothen the surface of it such that the maximum depth should be $8 \mathrm{~mm}$.

- Using the grooving tool, make a groove in the middle of the brass cup.

- Now, start turning the device hand by setting the number of revolutions per second. Observe the sample in the cup and count the number of blows as N. Stop the device when the soil sample from either side encounter each other a little. Note down all the values. 


\section{Journal of Student Research}

Fourth Middle East College Student Research Conference, Muscat, Sultanate of Oman

- If the soil is too dry, $\mathrm{N}$ will be more than 35 . In such case, add more water to the sample and try again.

- If the soil is too wet, $\mathrm{N}$ will be less than 25 . Take a new soil sample and mix water less than before and try again.

- Clean the copper cup with wet tissues every time after replacing the sample.

- Determine the water content of each of that samples by keeping those samples in oven for 24 hrs.

- Repeat the process for 4 to 5 trials and then plot a graph by taking the number of revolutions on $\mathrm{x}$-axis and moisture content on y axis.

- From the graph, at 25 number of blows, the moisture content on y axis is noted as Liquid Limit of that sample. 


\section{Journal of Student Research}

Fourth Middle East College Student Research Conference, Muscat, Sultanate of Oman

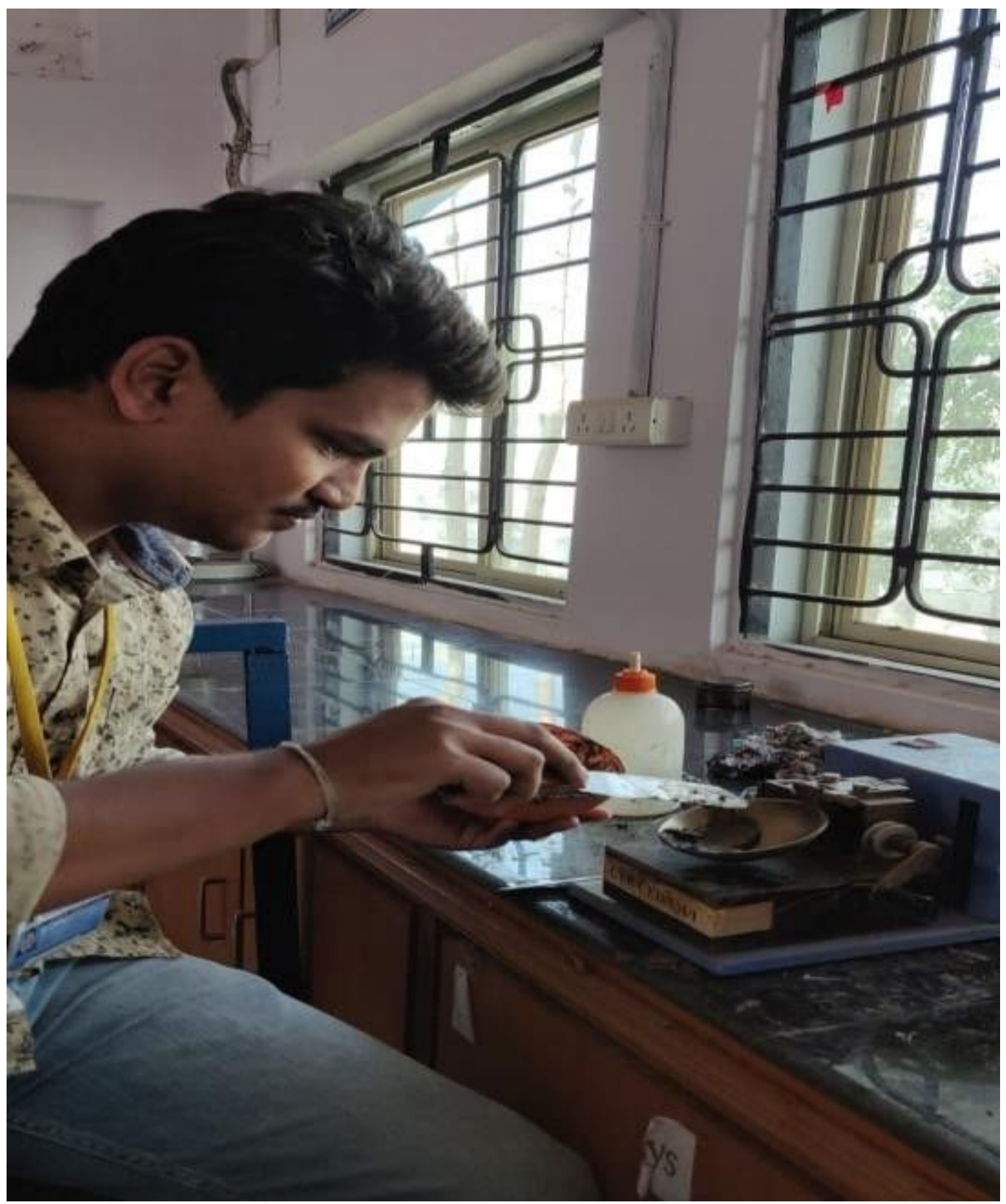

Figure 7. Performing Liquid Limit Test

\subsection{Plastic Limit Test (ASTM D-4318)}

- Initially take 50 grams of soil passed through a No. 40 sieve.

- That soil sample is mixed using some amount of water and mix uniformly.

- Then, rods of diameter $3.2 \mathrm{~mm}$ are made on a porcelain glass with the palm. Adjust the quantity of water and soil as per required to get the rod-shaped structure.

- The rod is made into pieces and then weigh it and kept it for drying in the oven. 


\section{Journal of Student Research}

Fourth Middle East College Student Research Conference, Muscat, Sultanate of Oman

- Two to three trials are performed to get accurate results.

- After 24 hrs. of oven dry, the soil masses are again checked for weight.

- Then using the specified formulae, Plastic Limit of the soil can be determined

- Plasticity Index of any soil sample is obtained by reducing the plastic limit value from liquid limit value of that soil sample.

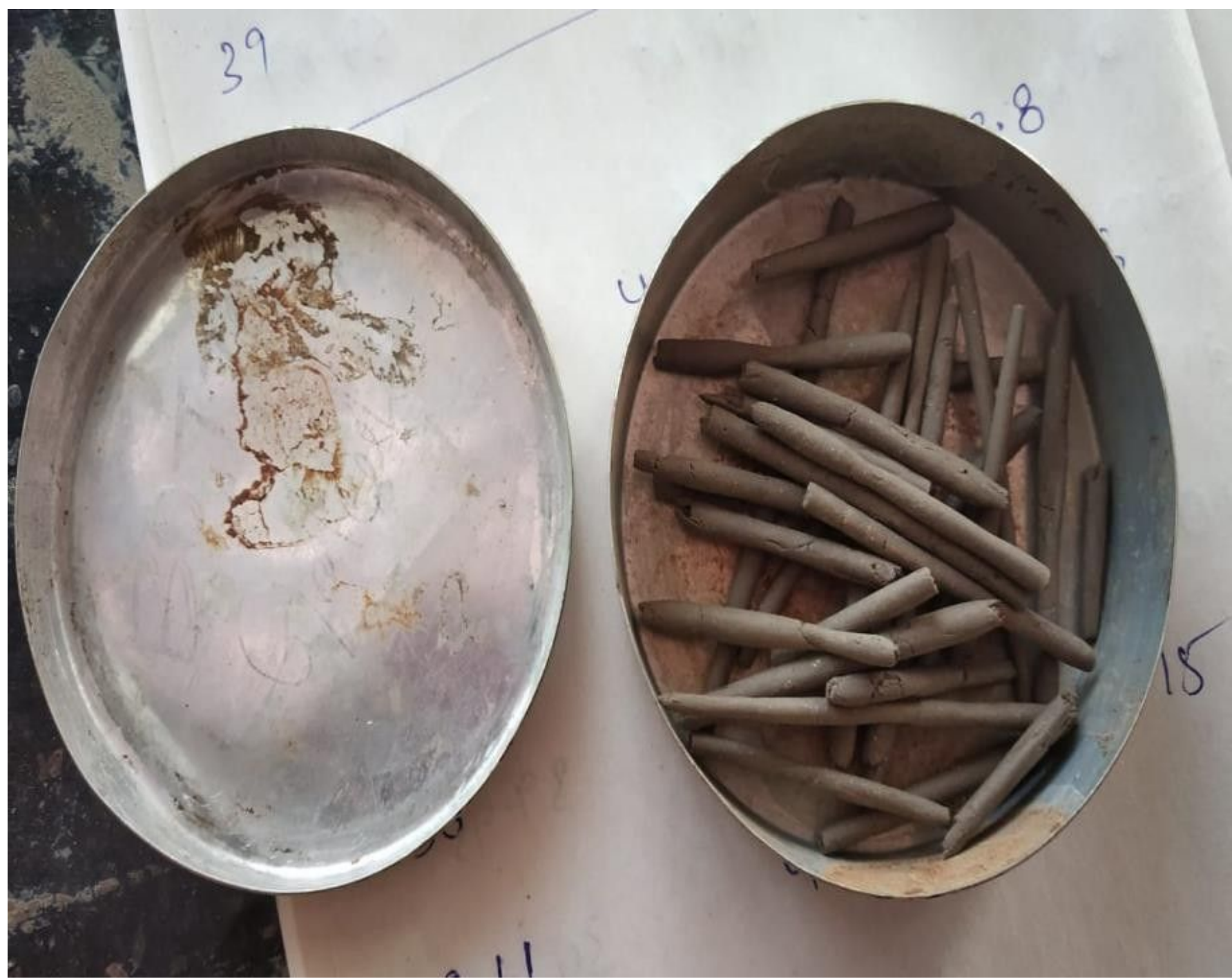

Figure 8. Plastic Limit test samples

\subsection{Standard Proctor Test (ASTM D-698)}

- Initially, $2.5 \mathrm{kgs}$ of oven dried soil sample is taken into a big tray and mixed thoroughly with the specified amount of water. The water quantity to be mixed depends on the soil composition.

- The sample is then placed in 3 layers, in a mould of capacity $1000 \mathrm{cc}$ whose weight is previously noted. In each layer, 25 blows are given with a $2.6 \mathrm{~kg}$ rammer from a height of $310 \mathrm{~mm}$. After 3 consecutive layers, collar of the mould is removed and surplus soil is trimmed from the mould and weighed. 


\section{Journal of Student Research}

Fourth Middle East College Student Research Conference, Muscat, Sultanate of Oman

- Repeat the same process for other 3 to 4 water contents also.

- From each sample, some amount of soil is taken for finding out moisture content of that soil sample

- After oven dry, determine the dry density of each of the samples and then plot a graph by taking moisture content on $\mathrm{x}$ axis and dry density on y axis. From the results of the graph, Maximum Dry Density and Optimum Moisture Content are determined.

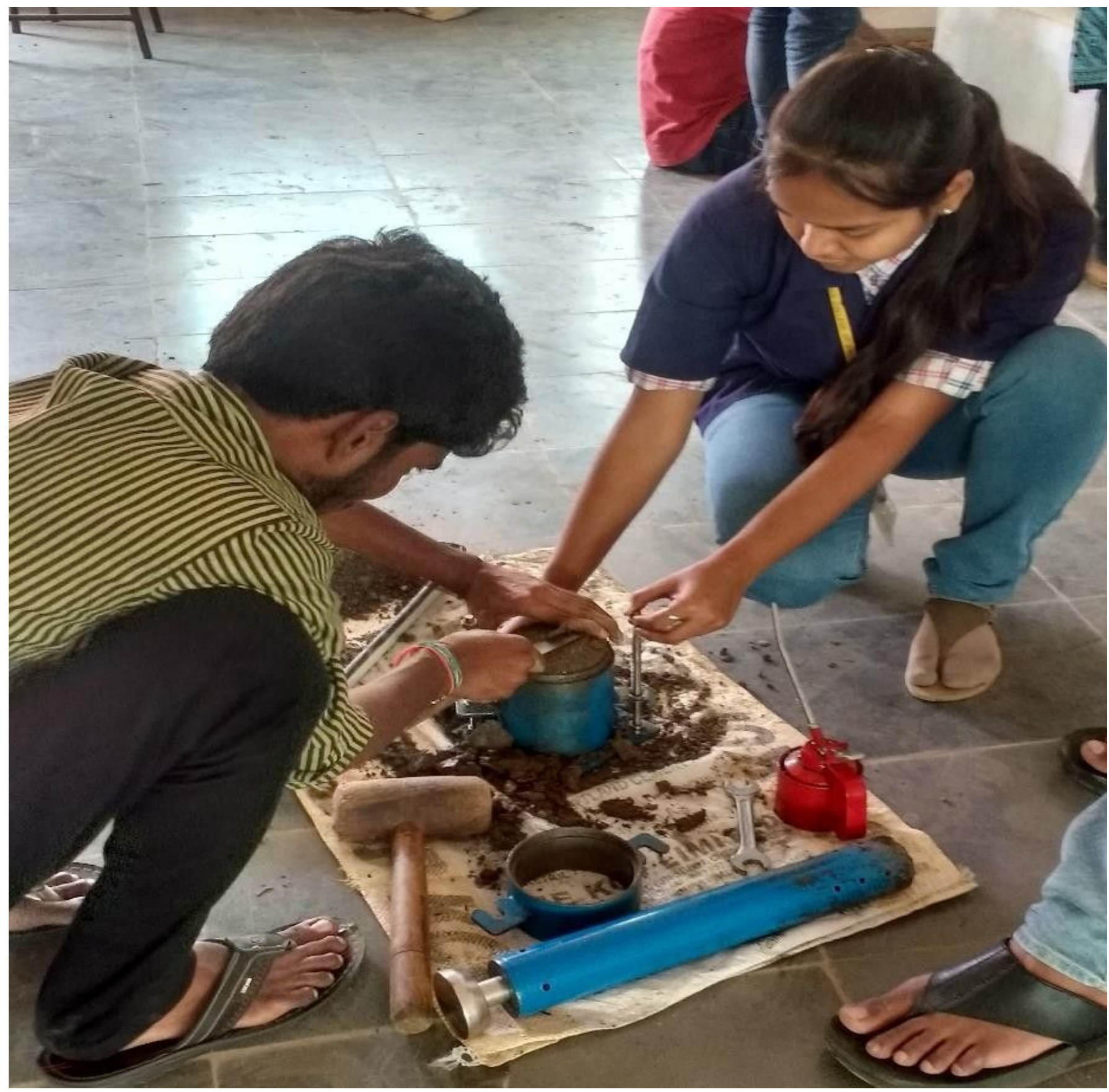

Figure 9. Performing Standard Proctor Test

\section{Results and Discussions:}

Different tests are conducted on the soil as well as on the soil mixed with required proportions of 


\section{Journal of Student Research}

Fourth Middle East College Student Research Conference, Muscat, Sultanate of Oman

Gypsum. Based on the results obtained, their variations and comparisons are shown below:

\subsection{Specific Gravity Test:}

\begin{tabular}{|l|l|l|l|l|l|}
\hline & Soil & Soil+ 2\% G & Soil+ 4\% G & Soil+ 6\% G & Soil+ 8\% G \\
\hline G & 2.46 & 2.47 & 2.46 & 2.47 & 2.45 \\
\hline & & & & & \\
\hline
\end{tabular}

Table 1. Results of Specific Gravity Test

From this test it is observed that, Specific Gravity of soil when stabilized with different percentages of Gypsum, has very negligible variation. This might be because of its fine nature and no reaction like cement with water. Gypsum is not a pozzolanic material. It has only filler nature. The percentages of Gypsum addition are also very less, so it might not effect the Specific Gravity.

\subsection{Liquid Limit test:}

\subsubsection{For Natural Soil}

\section{LIQUID LIMIT}

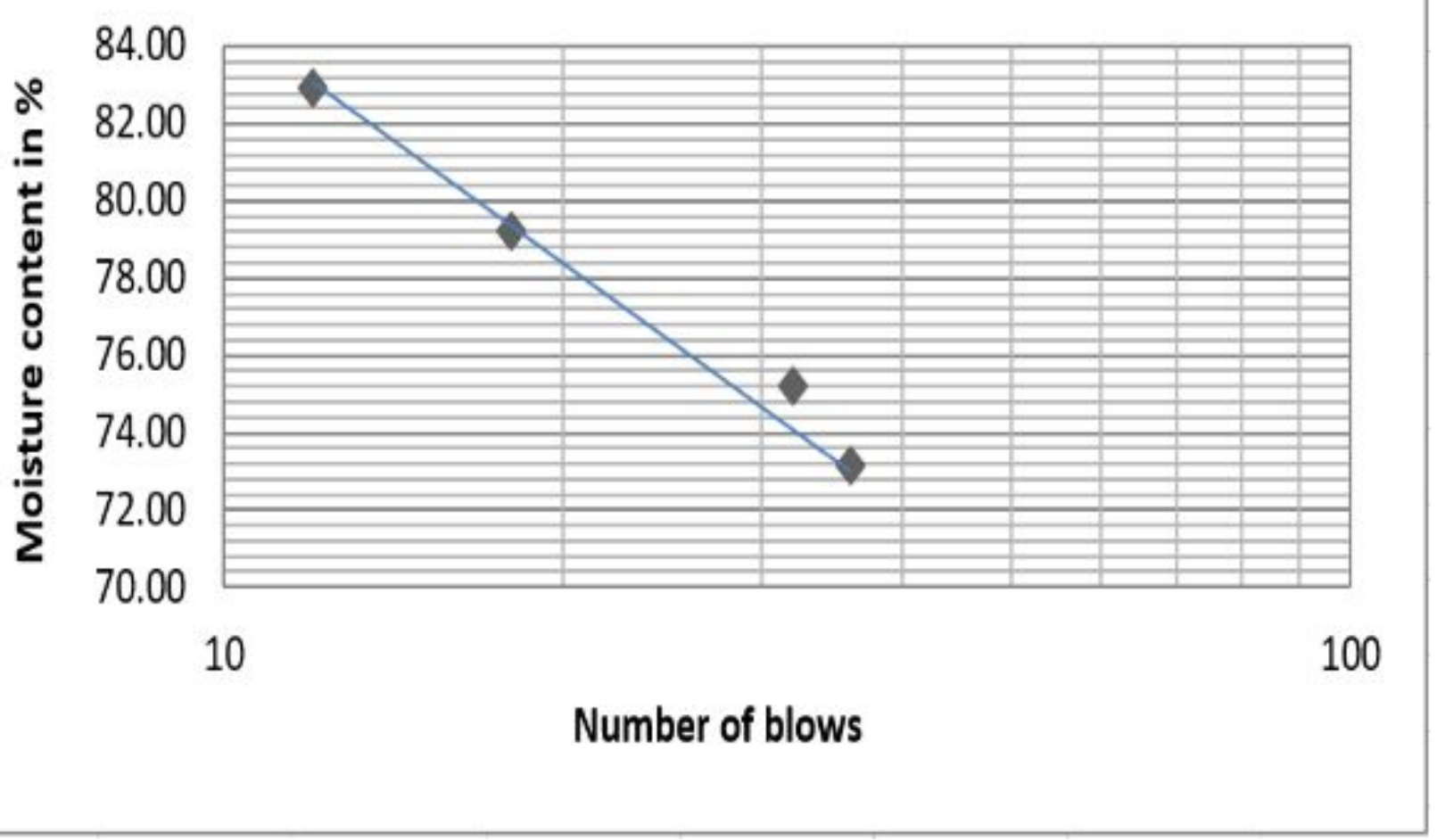

Figure 10. Graph showing Moisture content in soil

\subsubsection{Soil + 2\% Gypsum}




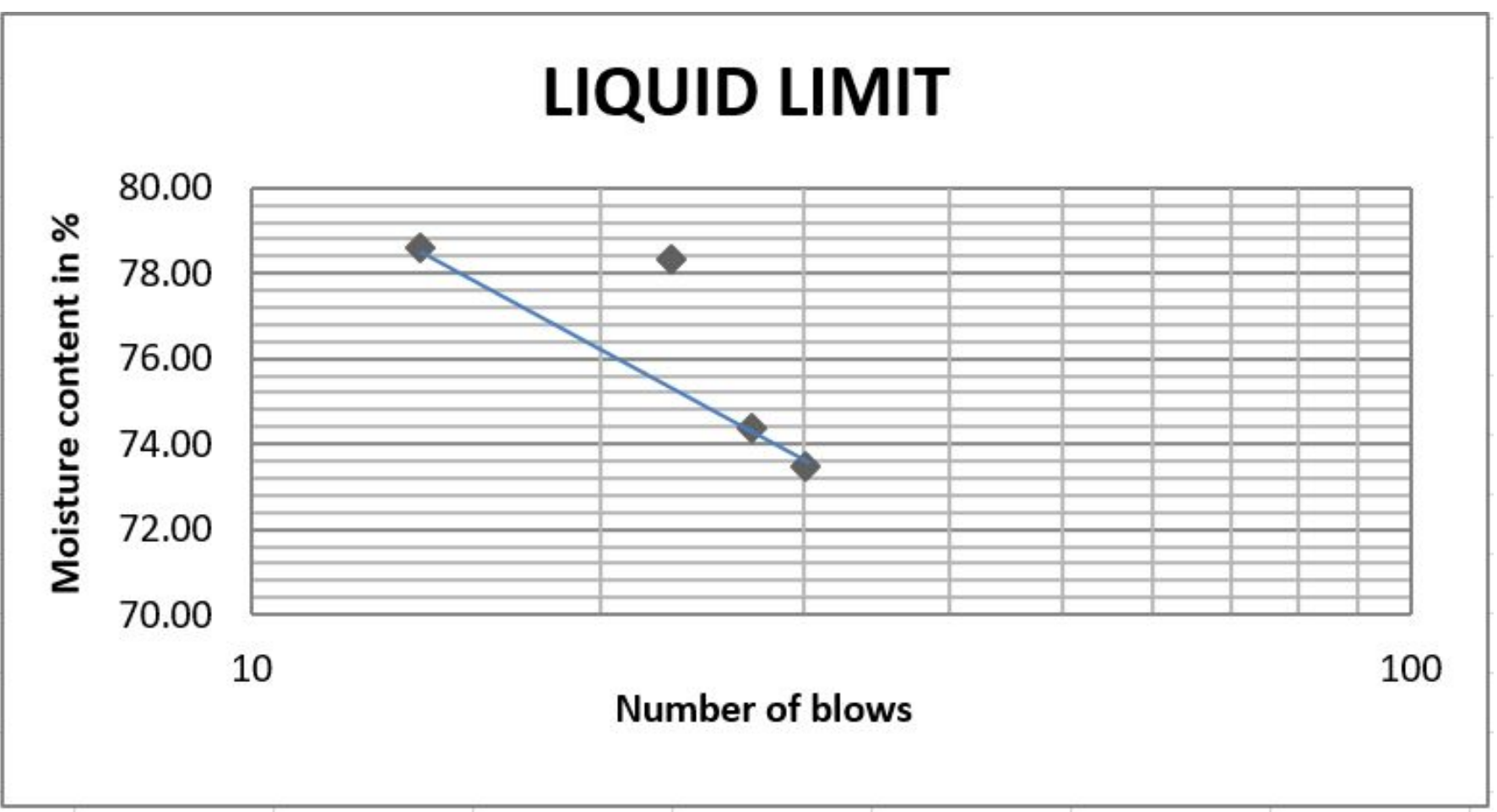

Figure 11. Graph showing Moisture content in soil + 2\% Gypsum

\subsubsection{Soil + 4\% Gypsum}

\section{LIQUID LIMIT}

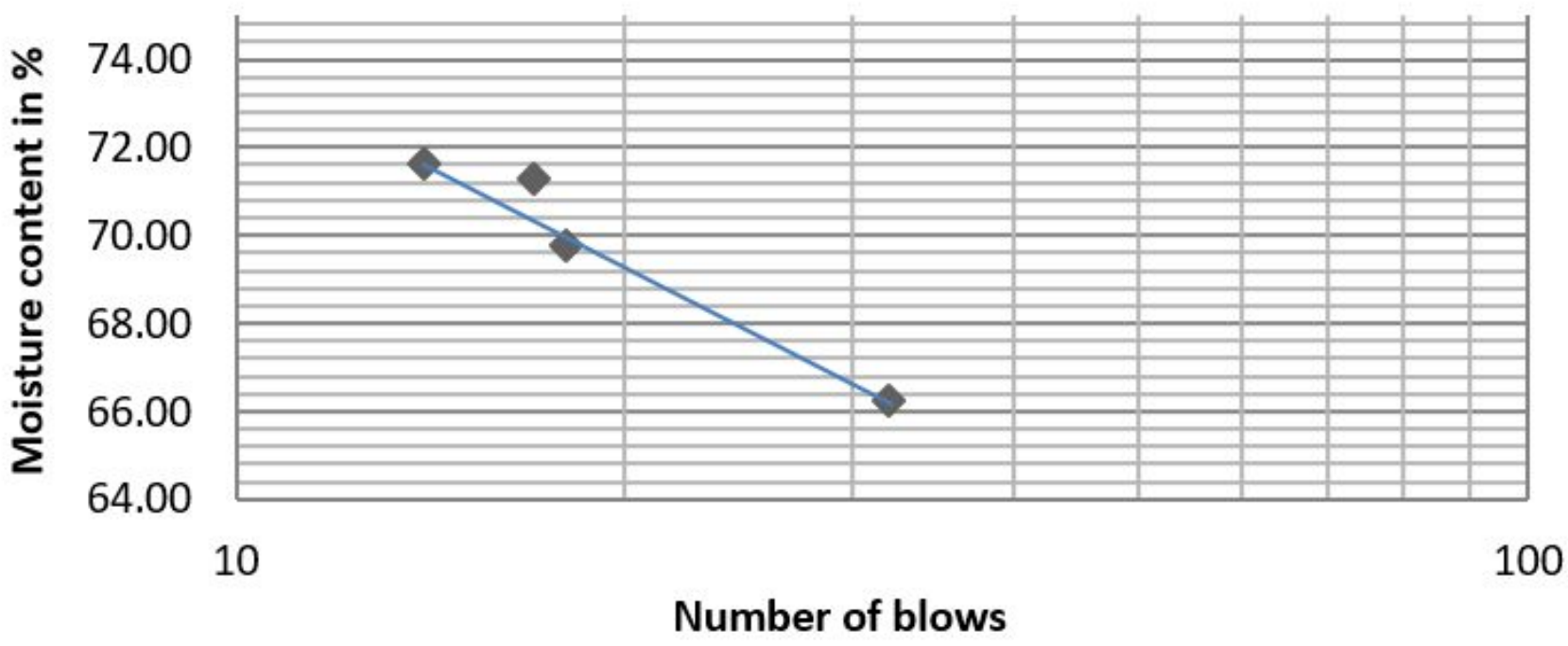

Figure 12. Graph showing Moisture content in soil + 4\% Gypsum

4.2.4 Soil + 6\% Gypsum 


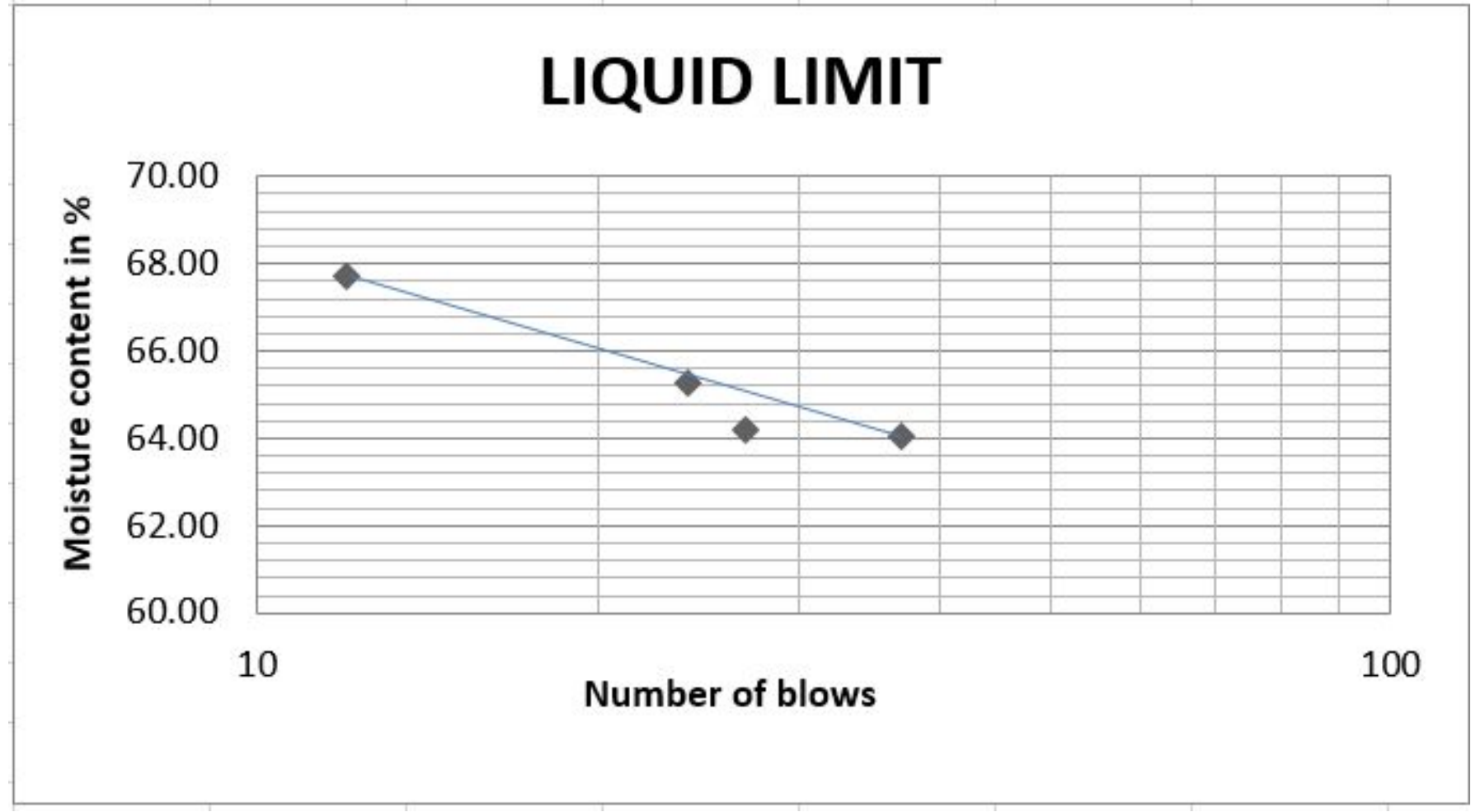

Figure 13. Graph showing Moisture content in soil + 6\% Gypsum

\subsubsection{Soil + 8\% Gypsum}

\section{LIQUID LIMIT}

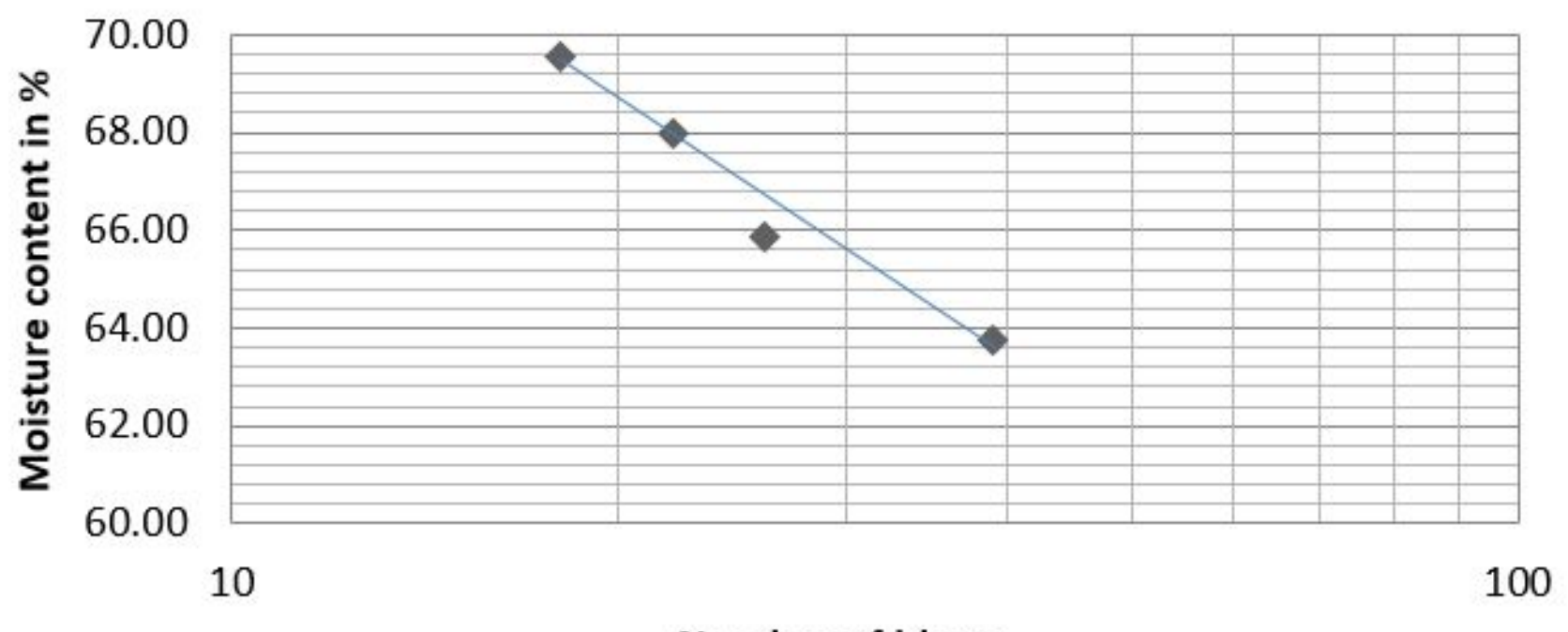

Number of blows

Figure 14. Graph showing Moisture content in soil + 8\% Gypsum

\begin{tabular}{|l|l|l|l|l|l|}
\hline & Soil & Soil+ 2\% G & Soil+ 4\% G & Soil+ 6\% G & Soil+ 8\% G \\
\hline LL & 76.2 & 74.6 & 67.6 & 65.2 & 66.8 \\
\hline & & & & & \\
\hline
\end{tabular}


Table 2. Results of Liquid Limit Test

Liquid limit of soil is used to predict the consolidation properties of soil while calculating allowable bearing capacity \& settlement of foundation. Liquid Limit of Natural soil is high when compared to other samples. A high Liquid Limit generally Indicates high shrinkage possibility. It is observed that with the addition of $6 \%$ of gypsum to the soil, Liquid Limit value reduced from 76.2 to 65.2, thus decreasing the possibility of swelling.

\subsection{Plastic Limit:}

\begin{tabular}{|l|l|l|l|l|l|}
\hline & Soil & Soil+ 2\% G & Soil+ 4\% G & Soil + 6\% G & Soil+ 8\% G \\
\hline PL (\%) & 32.12 & 31.79 & 30.88 & 30.37 & 30.46 \\
\hline & & & & & \\
\hline
\end{tabular}

Table 3. Results of Plastic Limit Test

The water content at which a soil changes from the plastic state to a semisolid state. As the moisture content is increased, plasticity increases up to a maximum, depending on the nature of the clay. Plastic limit of Natural soil is more when compared to other soil samples. From the results, it indicates that, at 6\% addition of Gypsum, it is showing better plastic limit properties.

\subsection{Standard Proctor Test:}

\subsubsection{For Natural Soil}

\section{STANDARD PROCTOR TEST}

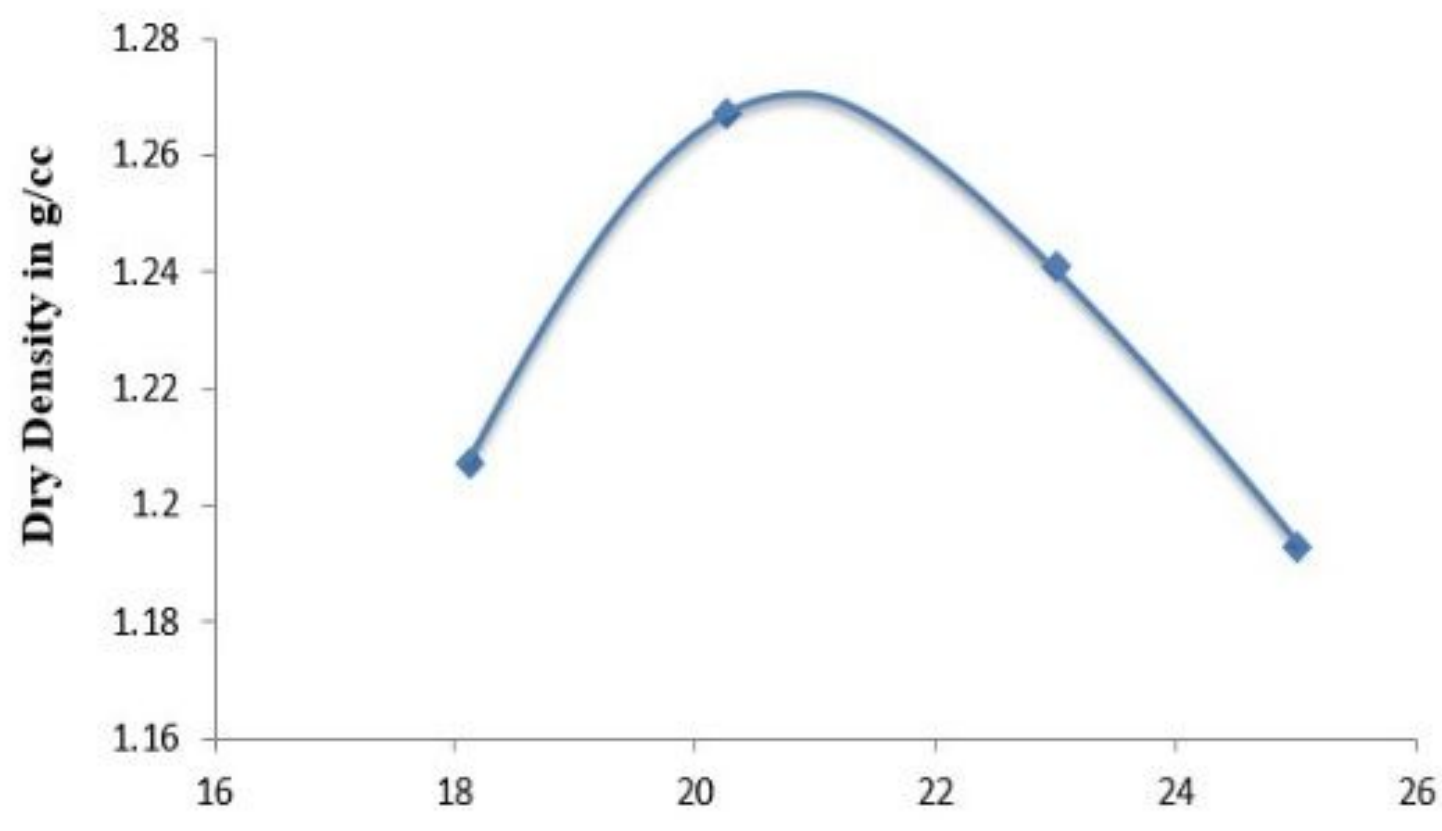

Moisture Content in \% 


\section{Journal of Student Research}

Fourth Middle East College Student Research Conference, Muscat, Sultanate of Oman

Figure 15. Graph showing variation of Dry density with Moisture content in soil sample

\subsubsection{Soil + 2\% Gypsum}

\section{STANDARD PROCTOR TEST}

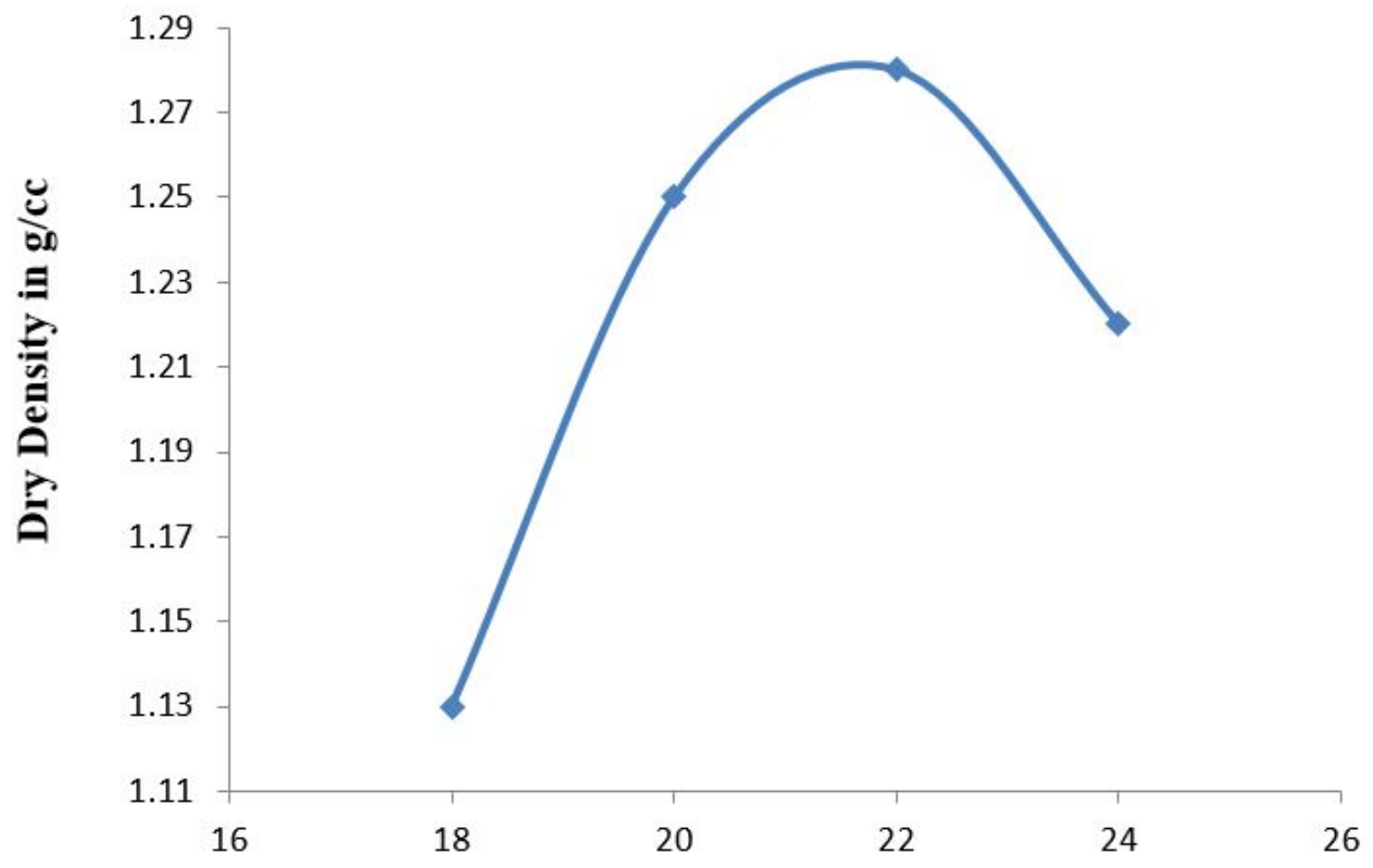

Moisture Content in \%

Figure 16. Graph showing variation of Dry density with Moisture content in soil sample $+2 \%$ Gypsum 4.4.3 Soil + 4\% Gypsum 


\section{STANDARD PROCTOR TEST}

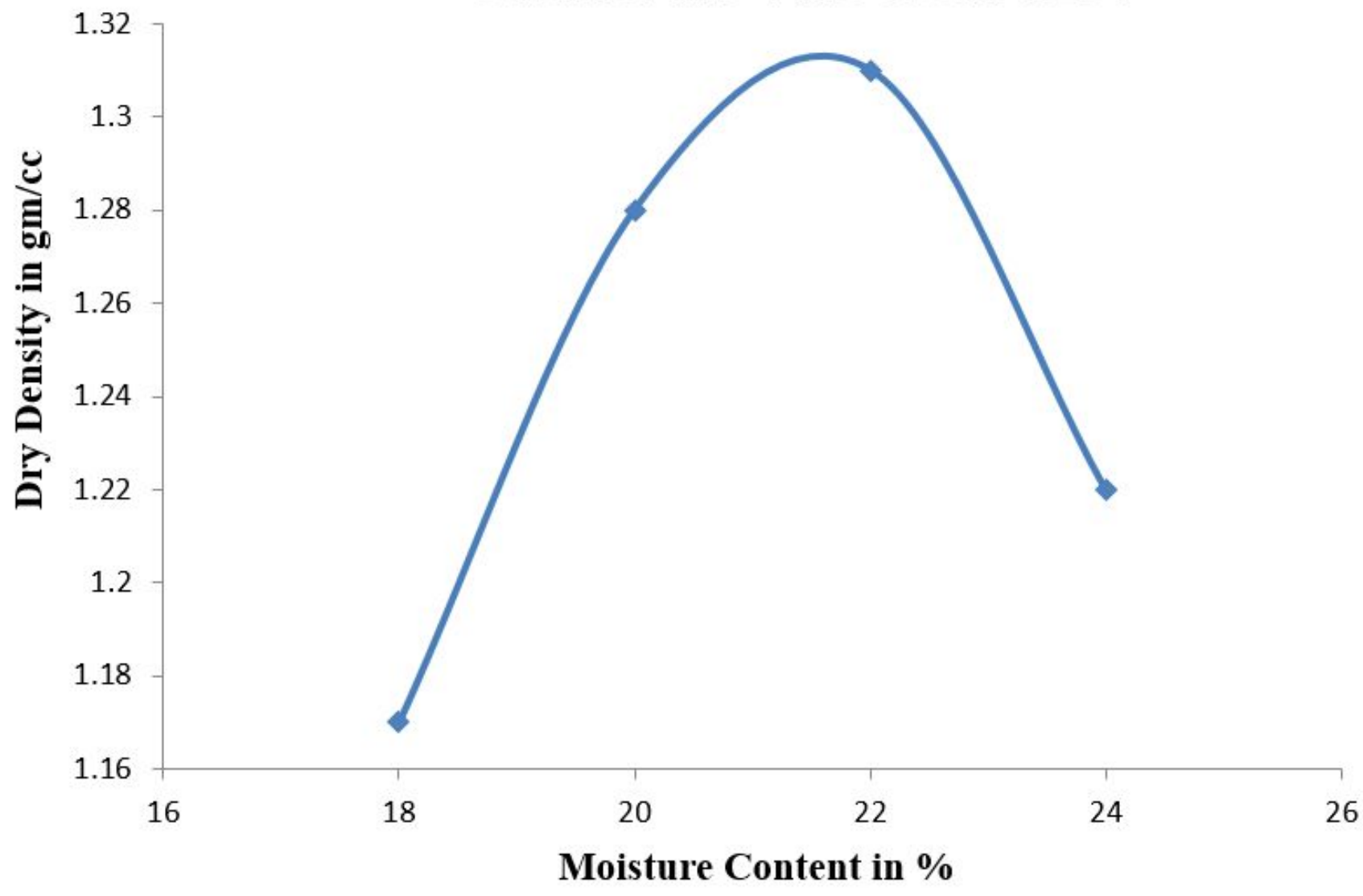

Figure 17. Graph showing variation of Dry density with Moisture content in soil sample + 4\% Gypsum 4.4.4 Soil + 6\% Gypsum 


\section{STANDARD PROCTOR TEST}

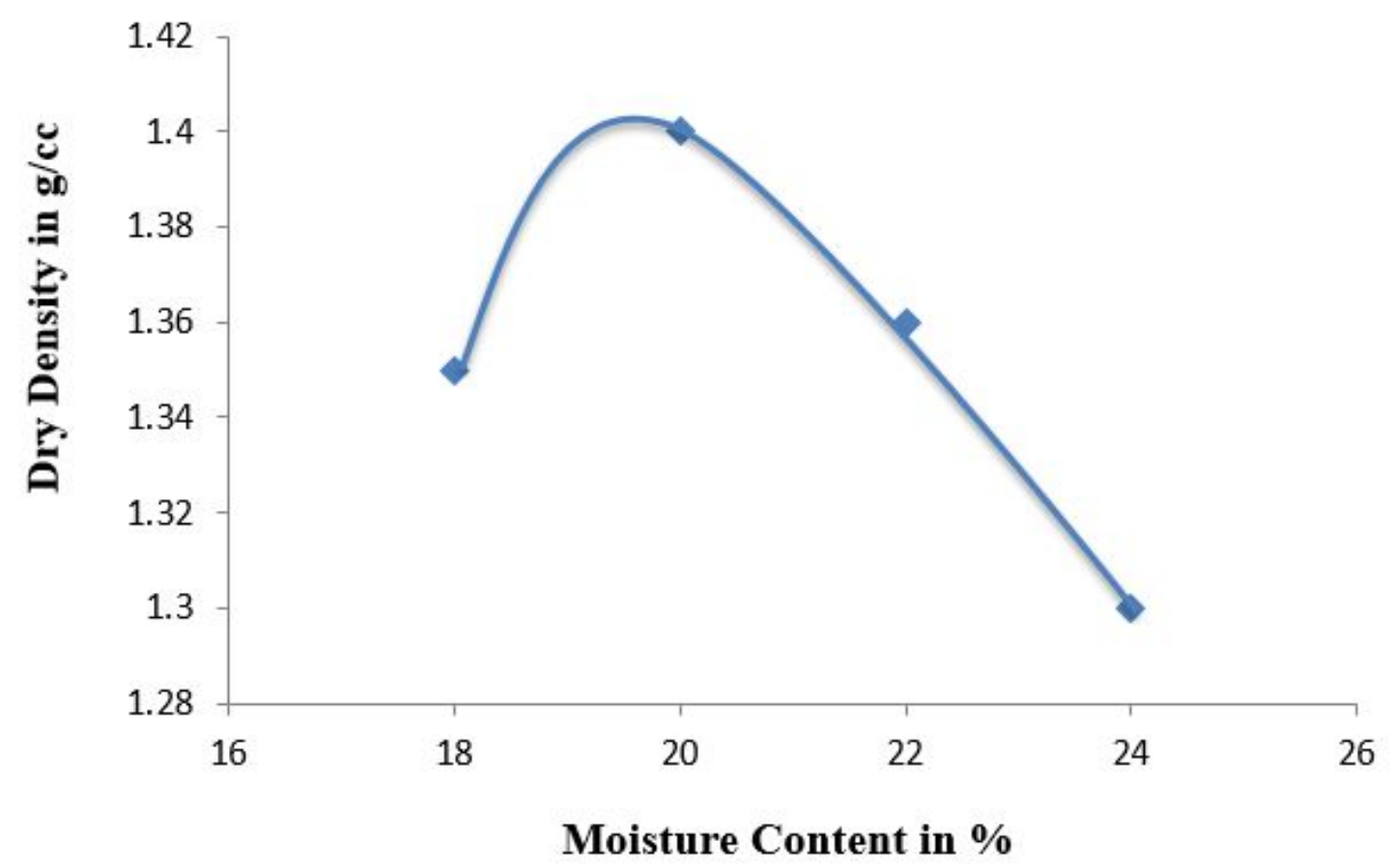

Figure 18. Graph showing variation of Dry density with Moisture content in soil sample + 6\% Gypsum

\subsubsection{Soil + 8\% Gypsum}




\section{STANDARD PROCTOR TEST}

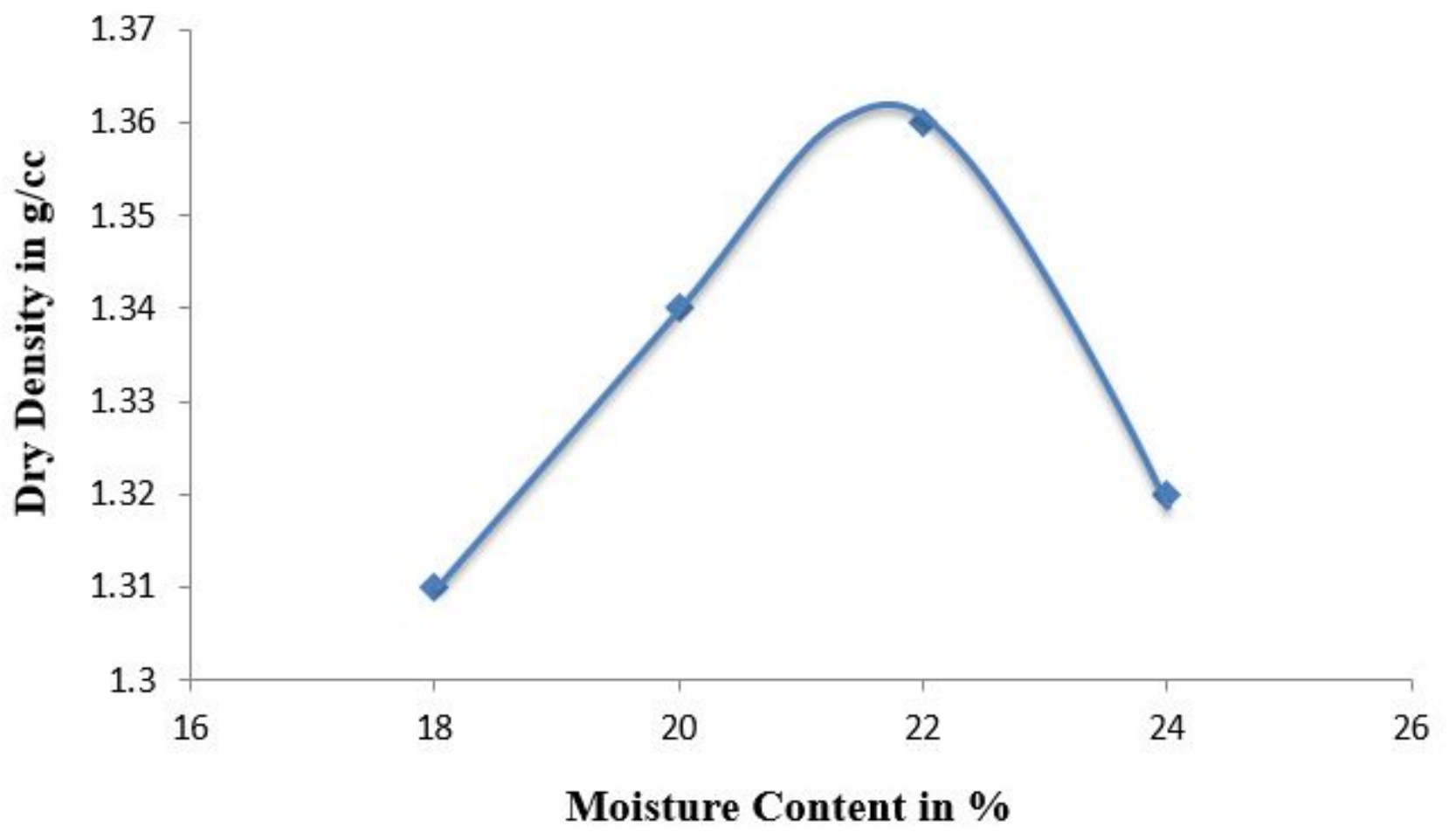

Figure 19. Graph showing variation of Dry density with Moisture content in soil sample + g\% Gypsum

The Moisture content at which Maximum dry density is obtained by the compaction of soil is its optimum moisture content. It should be noted that for moisture contents greater than the optimum, the use of heavier compaction effort will have only a small effect on increasing dry density. For a water content less than O.M.C, the soil is tough in nature having void spaces and porosity which causes lower dry density attainment. From the results, higher dry density value is obtained at lower OMC value on addition of $6 \%$ of Gypsum to the soil. Beyond 6\%, MDD value is again decreasing.

\begin{tabular}{|l|l|l|l|l|l|}
\hline & G & LL (\%) & PL (\%) & OMC (\%) & MDD (g/cc) \\
\hline Natural Soil & 2.46 & 76.2 & 32.12 & 21 & 1.27 \\
\hline Soil + 2\% Gypsum & 2.47 & 74.6 & 31.79 & 21.5 & 1.275 \\
\hline Soil + 4\% Gypsum & 2.46 & 67.6 & 30.88 & 21.7 & 1.31 \\
\hline Soil + 6\% Gypsum & 2.47 & 65.2 & 30.37 & 19.5 & 1.4 \\
\hline Soil + 8\% Gypsum & 2.45 & 66.8 & 30.46 & 21.8 & 1.362 \\
\hline
\end{tabular}

Table 4. Comparison Table showing results tests on soil and different percentages of Gypsum

\section{Conclusions}

- In this experimental study, soil is mixed with different percentages of Gypsum $(2 \%, 4 \%, 6 \%$, and $8 \%)$ and tests are performed. Best results are obtained on the addition of $6 \%$ of Gypsum to the soil. Further experiments are being carried out on this sample on addition of $2 \%$ of Calcium Chloride. 


\section{Journal of Student Research}

Fourth Middle East College Student Research Conference, Muscat, Sultanate of Oman

- The Optimum Moisture Content (OMC) and Maximum Dry Density (MDD) of natural soil are $21 \%$ and $1.27 \mathrm{~g} / \mathrm{cc}$ respectively. Whereas, for soil mixed with 6\% Gypsum they are $19.5 \%$ and $1.4 \mathrm{~g} / \mathrm{cc}$ respectively. Soil will become stronger on addition of $6 \%$ of Gypsum to it.

- Specific Gravity of soil has no much variation after stabilization as it has no reacting potential.

- Liquid limit and Plastic Limit also have advisable results on addition of $6 \%$ of Gypsum to the Natural soil.

\section{References}

Attoh-Okine, N. (1995). Lime treatment of laterite soils and gravels - revisited. Construction and Building Materials, 9(5), 283-287. doi: 10.1016/0950-0618(95)00030-j.

Barnes, G. (2010). Soil mechanics (3rd ed.). New York: Palgrave Macmillan.

Brahmachary, T. (2017). Soil Stabilization using Fly Ash and Cotton Fiber. International Journal of Trend in Scientific Research and Development, Volume-1(Issue-6), 1173-1181. doi: 10.31142/ijtsrd2493.

Dhon, S., \& Borkar, D. (2018). Stabilization of Soil by Plastic waste. IJSRD - International Journal for Scientific Research \& Development, 6(09).

Das, B. (2009). Soil mechanics laboratory manual (8th ed.). New York: Oxford University Press, Inc.

Effect of Calcium Chloride on Geotechnical Properties of Black Cotton Soil Ramya. (2018). Advances In Materials Science And Engineering, 2(1). doi: 10.33140/amse/02/01/16

Kassim, K.A., R. Hamir and K. Kok (2005). Modification and stabilization of Malaysian cohesive soils with lime. Geotech. Eng., 36(2)

Sikarwar, B., \& Trivedi, M. (2017). Stabilization of soil by using Gypsum. International Journal for Scientific Research \& Development, 5(03).

Tiwari A., Mahiyar H. K. (2014). Experimental study on Stabilization of black cotton soil by fly ash, coconut coir fibers and crushed glass. International Journal of Engineering Technology and Advanced Engineering, 4(11). 